\title{
Interactive comment on "A novel causal structure-based framework for comparing basin-wide water-energy-food-ecology nexuses applied to the data-limited Amu Darya and Syr Darya river basins" by Haiyang Shi et al.
}

\author{
Murugesu Sivapalan (Editor) \\ sivapala@illinois.edu \\ Received and published: 23 December 2020
}

This is a very interesting and valuable paper. The paper offers an interesting framework for comparative analysis of transboundary river water management and is therefore an important contribution to this special issue on transboundary rivers.

The authors have benefited from valuable constructive comments by two reviewers, bot of whom wanted more explanation and discussion of the methods used and the results. The authors have also responded positively to these comments and have agreed to do

Printer-friendly version

Discussion paper 
the revisions requested.

Since the revisions requested and proposed are rather substantial, I will seek the opinions of the reviewers one more time. Please submit the revised version as soon as possible and I will endeavor to get it reviewed expeditiously.

Interactive comment on Hydrol. Earth Syst. Sci. Discuss., https://doi.org/10.5194/hess-2020-

Interactive

comment 482, 2020. 